\title{
Glyceraldehyde-3-phosphate dehydrogenase expression in Trichoderma harzianum is repressed during conidiation and mycoparasitism
}

\author{
Mariela Puyesky, ${ }^{2}$ Patricia Ponce-Noyola, ${ }^{1} \dagger$ Benjamin A. Horwitz ${ }^{2}$ \\ and Alfredo Herrera-Estrella'
} Author for correspondence: Alfredo Herrera-Estrella. Tel: +52 462 39600. Fax : +52 462 45849/45846.
e-mail: aherrera@irapuato.ira.cinvestav.mx

\footnotetext{
1 Centro de Investigación y Estudios Avanzados (CINVESTAV), Plant Biotechnology and Genetic Engineering Unit, $\mathrm{Km} 9 \cdot 6$ del libramiento Norte de la Carretera Irapuato/León, Apdo Postal 629, Irapuato, Gto, 36500 Mexico

2 Department of Biology, Technion - Israel Institute of Technology, Haifa 32000, Israel
}

\begin{abstract}
A glyceraldehyde-3-phosphate dehydrogenase (gpd) cDNA was isolated from the filamentous fungus Trichoderma harzianum in the course of a search for light-regulated genes in this organism. There is apparently only one copy of gpd in the T. harzianum genome, and its sequence is most similar to that of other filamentous ascomycetes. Trichoderma grows in the soil as a saprophyte or mycoparasite. A brief pulse of blue light, or nutrient depletion, induces sporulation, which is accompanied by altered patterns of abundance of specific polypeptides. Mycoparasitic development is also accompanied by changes in gene expression. The abundance of gpd mRNA decreased strongly during sporulation, and was lowest in samples consisting of mature conidiophores and conidia. When T. harzianum was grown in the presence of cell walls of the phytopathogen Rhizoctonia solani, the gpd mRNA level was much lower than in similar cultures grown on glucose. The repression of gpd, which is usually considered a constitutively expressed gene, may be part of the switch to sporulation or to the simulated mycoparasitic state. The implications of these findings for the use of gpd promoters to confer high constitutive expression are discussed.
\end{abstract}

Keywords: glyceraldehyde-3-phosphate dehydrogenase, biocontrol, sporulation, fungi, Trichoderma harzianum

\section{INTRODUCTION}

The common soil fungus Trichoderma harzianum is well known for its potential as a biological control agent of phytopathogenic fungi. Another important characteristic of the genus is its response to blue light. In total darkness, $T$. harzianum (some of the isolates widely used in photobiology are referred to as Trichoderma viride in work published before the early 1980s) grows indefinitely as a mycelium, provided that nutrients are not limiting. A brief pulse of blue light, as well as nutrient limitation, induce sporulation. In a symmetrically expanding colony, conidiophores are produced in

\footnotetext{
†Present address: Instituto de Investigación en Biología Experimental, Universidad de Guanajuato, Gto, Mexico.

The EMBL accession number for the sequence reported in this paper is
} Y12542. a well-defined ring located where the colony perimeter was at the moment of photoinduction (Gressel \& Rau, 1983; Betina, 1984). The inductive pulse can be as short as $10 \mathrm{~ns}$ and morphogenesis then proceeds in the dark with mature spores produced by $24 \mathrm{~h}$ (Horwitz et al., 1990).

Mycoparasitism is thought to be the main mechanism involved in biological control mediated by species of Trichoderma (Chet \& Baker, 1981). During mycoparasitism Trichoderma coils around the hyphae of its host, forms appressoria-like structures, and finally penetrates it. Hydrolytic enzymes such as 1,3- $\beta$-glucanases, proteases and chitinases are important for mycoparasitism, and it is becoming clear that the expression of these genes is regulated during the mycoparasitic interaction (Flores et al., 1997; Carsolio et al., 1994; Inbar \& Chet, 1995). Additionally, the expression of some of the mycoparasitism-related genes seems to be regulated 
during development and affected by stress (Flores et al., 1997; Carsolio et al., 1994). At least some of these changes in gene expression can be induced in shake culture when the mycoparasitic state is simulated by growth on cell walls of the pathogen Rhizoctonia solani (Goldman et al., 1992; Geremia et al., 1993). A catabolite-repressed protein which is a likely component of the cell wall is also induced by growth on chitin (Lora et al., 1994).

The changes in gene expression that accompany conidiation of filamentous ascomycetes have been studied in detail, beginning with studies of enzyme activity (Urey, 1971; Weiss \& Turian, 1966), and more recently at the mRNA level (Roberts \& Yanofsky, 1989). In particular, three regulatory genes of Aspergillus nidulans can be placed on a linear pathway; the first of these, $b r l A$, can direct conidiophore development when expressed in mycelia (Adams et al., 1988; Timberlake, 1993). For the most part, though, the functions, and polypeptides, corresponding to conidiation-specific genes are unknown. An exception is the Neurospora hydrophobin gene known as ccg-2, eas or bli-7, and its Aspergillus homologue rodA (Stringer et al., 1991). The various names that appeared in the literature for the Neurospora hydrophobin gene reflect its multiple regulation: by the circadian clock, blue light, and nitrogen limitation (Lauter et al., 1992; Arpaia et al., 1993). Regulation by light and by the sporulation process itself are not necessarily the same. A zinc finger DNA-binding protein of Neurospora, encoded by $w c-1$, is specific for light regulation, and is autoregulated by blue light (Ballario et al., 1996).

Little information has been available on the molecular correlation of photoinduction and sporulation in Trichoderma, though biochemical changes can be detected soon after induction (Farkas et al., 1990). The earliest stages of conidiation, in which aerial hyphae are stabilized, are not accompanied by changes in abundant polypeptides. Major differences, though, were detected when the synchronous, photoinduced ring of developing conidiophores was harvested separately from the mycelial mat (Baum \& Horwitz, 1991). Together with the initiation of conidiophore development, an abundant polypeptide appears in conidiophore-enriched membrane fractions; several other proteins also decrease in abundance. One of the most prominent down-regulated species is a soluble polypeptide of about $39 \mathrm{kDa}$. In this study we used polyclonal antibodies to obtain the corresponding CDNA clones from an expression library and identified the gene as $g p d$, and followed the regulation of the mRNA during conidiation and simulated mycoparasitism.

\section{METHODS}

Growth, photoinduction and simulated mycoparasitism. $T$. harzianum, ATCC 32173 , was grown at $25-26^{\circ} \mathrm{C}$ on complete medium (PDYC: $24 \mathrm{~g}$ potato dextrose broth $\mathrm{l}^{-1}, 2 \mathrm{~g}$ yeast extract $l^{-1}, 1.2 \mathrm{~g}$ casein hydrolysate $\mathrm{l}^{-1}$; all from Difco). After $36 \mathrm{~h}$ growth in total darkness, colonies were photoinduced by a 4 min exposure to a standard blue source consisting of light from a cool-white fluorescent tube filtered through a blue acrylic filter (fluence rate $2 \mu \mathrm{mol} \mathrm{m}^{-2} \mathrm{~s}^{-1}$ ). Entire colonies were harvested by vacuum filtration after growth in stationary liquid culture: the inoculum was fixed to the bottom of the Petri dish with molten agar, and $12 \mathrm{ml}$ PDYC was added. To obtain conidiophore-enriched samples, the colonies were grown on filter paper soaked with PDYC medium: an $8 \mathrm{~cm}$ disk of Whatman 50 overlaying a $7 \mathrm{~cm}$ disk of Whatman 1, in a $9 \mathrm{~cm}$ plastic Petri dish. The conidiophore ring was scraped from the surface of the Whatman 50 filter paper with a spatula. Samples for RNA extraction were immediately frozen in liquid nitrogen. To obtain the growth curve for conidiophores, samples from three colonies each were dried overnight at $70^{\circ} \mathrm{C}$ on pre-weighed Whatman GF/C filters, and the dry weight was divided by three to obtain each point in Fig. 9 .

For simulated mycoparasitism, cultures were grown for $48 \mathrm{~h}$ in minimal medium with $2 \%$ glucose with shaking, under laboratory light. At zero time (Fig. 8), the mycelium was collected by suction onto filter paper and washed with sterile distilled water. The sample was divided in two, and one was transferred to minimal medium with $2 \%$ glucose, and the other to minimal medium with $0.2 \% R$. solani cell walls as carbon source. The cultures were then grown with shaking for a further $48 \mathrm{~h}$, and samples harvested by filtration at the times indicated in Fig. 9.

Protein extraction and antibody production. Samples were ground for $1 \mathrm{~min}$ at medium speed with a Polytron homogenizer (Brinkmann) in $30 \mathrm{mM}$ Tris $/ \mathrm{HCl} \mathrm{pH} \mathrm{7.0,20} \mathrm{mM}$ $\mathrm{NaCl}, 0.3 \mathrm{M}$ sucrose, $5 \mathrm{mM} \mathrm{MgCl}_{2}, 1 \mathrm{mM} \mathrm{PMSF}$, and centrifuged $10 \mathrm{~min}$ at $12000 \mathrm{~g}$. The supernatant was centrifuged $30 \mathrm{~min}$ at $100000 \mathrm{~g}$ in a Ti50 rotor (Beckman) to obtain a soluble protein fraction. Polypeptides were separated by SDS-PAGE, stained with Coomassie Blue, and the $39 \mathrm{kDa}$ band was cut from the gel. Combined excised bands from 60 lanes were equilibrated with Laemmli sample buffer and subjected to electrophoresis on a second SDS-PAGE gel, blotted to nitrocellulose (BA45; Schleicher \& Schuell) and detected by staining with Ponceau Red. The nitrocellulose strips with the $39 \mathrm{kDa}$ band were vacuum-dried and dissolved in DMSO, mixed at $1: 1$ with complete Freund's adjuvant, and used to immunize rabbits; about $20 \mu \mathrm{g}$ protein were used for the first injection and for a booster 3 weeks later. Serum obtained by bleeding the marginal ear vein at 10-14 $\mathrm{d}$ after the booster was used at 1:1000 dilution for Western blot analysis (Harlow \& Lane, 1988). Detection of the primary antibody was either with Protein A-peroxidase and $\mathrm{H}_{2} \mathrm{O}_{2} / 3,3^{\prime}$ diaminobenzidine, or by goat anti-rabbit IgG-alkaline phosphatase and 5-bromo-4-chloro-3-indolyl phosphate/nitro blue tetrazolium. Equal loading of lanes on the Western blots was confirmed by Ponceau Red staining after transfer.

Nucleic acid extraction and analysis. RNA was isolated by a modification of the phenol/SDS method (Ausubel et al., 1987). Samples $(2 \mathrm{~g})$ were ground to a fine powder in liquid nitrogen, and then suspended by shaking for $10 \mathrm{~min}$ in $4 \mathrm{ml}$ NTES $(0.1 \mathrm{M} \mathrm{NaCl}, 10 \mathrm{mM}$ Tris/HCl pH 7.5, $1 \mathrm{mM}$ EDTA, $1 \%$ SDS) and $3 \mathrm{ml}$ phenol/chloroform/isoamyl alcohol (25:24:1, by vol.). After centrifugation for $10 \mathrm{~min}$ at $7650 \mathrm{~g}$, nucleic acids were ethanol-precipitated from the aqueous phase; the pellet was redissolved and RNA was precipitated overnight on ice by addition of lithium acetate to a final concentration of $2 \mathrm{M}$, followed by a second ethanol precipitation. Northern analysis was by separation in formaldehyde agarose gels (Ausubel et al., 1987), blotting to Zeta-Probe GT membranes (Bio-Rad), and hybridization at $65^{\circ} \mathrm{C}$ in $7 \%$ SDS, $0.25 \mathrm{M}$ $\mathrm{Na}_{2} \mathrm{HPO}_{4}, \mathrm{pH} 7 \cdot 2$. The blots were washed twice for $30 \mathrm{~min}$ at 
$65^{\circ} \mathrm{C}$ in $10 \mathrm{mM} \mathrm{Na}{ }_{2} \mathrm{HPO}_{4}, \mathrm{pH} \mathrm{7.2,5 \%} \mathrm{SDS,} \mathrm{and} \mathrm{if} \mathrm{back-}$ ground was still present, for an additional $15 \mathrm{~min}$ in the same buffer with $1 \%$ SDS at $65^{\circ} \mathrm{C}$. Quantitative data in Fig. 9 were obtained by densitometric scanning of non-saturated autoradiograms. Southern blotting was to Hybond-N + (Amersham) according to the manufacturer's recommendations, or by alkaline blotting (transfer in $0.5 \mathrm{M} \mathrm{NaOH}, 1.5 \mathrm{M} \mathrm{NaCl}$ ). Fragments for use as probes were purified from agarose gels using glass milk, and labelled by random priming (DupontNEN). Poly(A) ${ }^{+}$RNA was obtained using the PolyAttract mRNA isolation system (Promega). Briefly, with total RNA as the starting material, the poly $(\mathrm{A})^{+} \mathrm{RNA}$ fraction was isolated using a biotinylated oligo(dT) primer to hybridize in solution to the $3^{\prime}$ poly $(\mathrm{A})^{+}$region. The hybrids were captured and washed at high stringency using streptavidin coupled to paramagnetic particles and a magnetic separation stand. The poly $(\mathrm{A})^{+} \mathrm{RNA}$ was eluted from the solid phase by addition of DEPC-treated water.

Library construction, screening and sequencing. Directional cDNA libraries were constructed in $\lambda$ ZAP (Stratagene) from poly $(\mathrm{A})^{+} \mathrm{RNA}$ of colonies 0,2 and $16 \mathrm{~h}$ after photoinduction. First strand cDNA synthesis was made with SuperScript RT (Gibco-BRL) instead of the reverse transcriptase supplied with Stratagene's $\lambda Z A P-c D N A$ synthesis kit. Second strand synthesis, ligation and digestion of adaptors, size selection and ligation to the vector arms were according to the supplier. For antibody screening, nitrocellulose filters were soaked with $10 \mathrm{mM}$ IPTG, dried and incubated $6-14 \mathrm{~h}$ on plates of about $3 \times 10^{4}$ plaques of the $2 \mathrm{~h}$ library (total $2 \times 10^{5}$ ) and blocked by incubation for $2 \mathrm{~h}$ in a mixture of four parts non-fat milk to one part Tris-buffered saline, then washed with Tris-buffered saline and incubated overnight in the pre-adsorbed $39 \mathrm{kDa}$ antiserum at 1:200 dilution. After two rounds of plaque purification, positive phage clones were rescued to plasmid form in pBluescript by in vivo excision using helper phage R408 (Stratagene). Sequencing was performed with doublestranded DNA of pGPDA1 as template, on an automated sequencer (Applied Biosystems; sequencing unit at the Weizmann Institute of Science, Rehovot, Israel), several oligonucleotides were synthesized (DNA synthesis unit, Department of Plant Genetic Engineering, CINVESTAV, Irapuato, Mexico) and used to sequence both strands.

\section{RESULTS}

\section{Isolation of Trichoderma gpd CDNA}

A prominent polypeptide band migrating at about $39 \mathrm{kDa}$ is down-regulated during conidiation (Fig. 1). Antibody raised against this band detected an abundant polypeptide that was strongly down-regulated in conidiophores (Fig. 2). At $8 \mathrm{~h}$, the earliest time at which conidiophores can be harvested, the signal is comparable to that in extracts of the whole colony. By $16 \mathrm{~h}$, when conidial differentiation has begun, a strong decrease is apparent, and by $24 \mathrm{~h}$, when mature conidia are present, the signal is very low, often near the limit of detection (Fig. 2). No decrease is noticeable in samples extracted from the entire colony (Figs 1 and 2). A $\lambda Z A P$ cDNA library constructed from poly $(\mathrm{A})^{+} \mathrm{RNA}$ of colonies $2 \mathrm{~h}$ after photoinduction was screened with the antibody. Thirteen positive clones were isolated by screening approximately $2 \times 10^{5}$ plaques. Of these, six were converted to plasmids by in vivo excision, and found to contain inserts of apparently identical size, $1.3 \mathrm{~kb}$, and

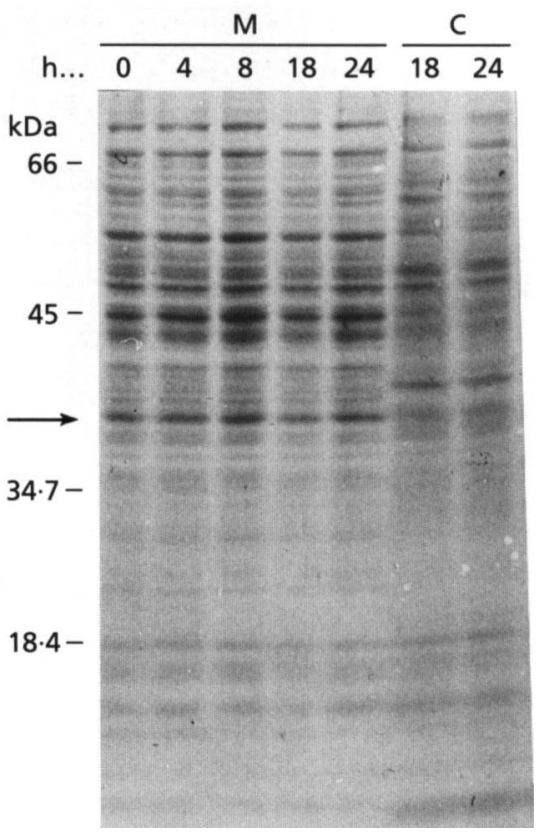

Fig. 1. Polypeptide patterns of mycelia and conidiophores. Soluble proteins from mycelial colonies grown in stationary liquid culture $(\mathrm{M})$ and conidiophores from colonies grown on filter paper soaked with liquid medium (C), were separated by SDS-PAGE and stained with Coomassie Blue. The arrow indicates the prominent band at approximately $39 \mathrm{kDa}$, against which antibodies were raised. Times in $h$ above each lane indicate time from photoinduction with $480 \mu \mathrm{mol} \mathrm{m}^{-2}$ blue light. At time zero, colonies were about $4 \mathrm{~cm}$ in diameter, after $36 \mathrm{~h}$ growth in total darkness. The experiment was repeated three times.

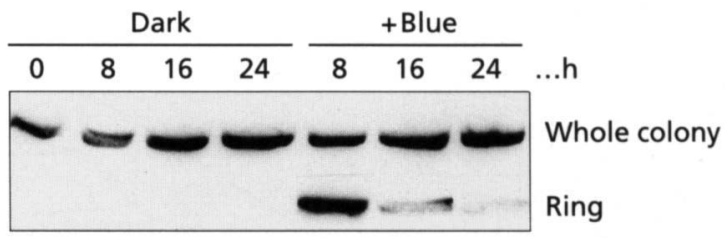

Fig. 2. Developmental regulation of the $39 \mathrm{kDa}$ polypeptide during conidiation. Western blot of soluble protein fractions extracted at the indicated times from colonies grown in stationary liquid culture (whole colony) or from conidiophores (conidiophore ring). Photoinduction was at $\mathrm{Oh}$ and $25 \mu \mathrm{g}$ protein was loaded per lane. Experiments were carried out in triplicate.

having the same restriction patterns upon digestion with KpnI, EcoRI, PstI and XhoI. In all six, a fusion protein about $6 \mathrm{kDa}$ larger than the polypeptide from darkgrown mycelia was detected by the antibody. The difference corresponds well, within the resolution of the gel, with the additional $45 \mathrm{kDa}$ peptide expected from the fusion.

The recognition of the fusion protein by the antibody, as well as the regulation of the corresponding mRNA 


\section{T. koningii 2 \\ T. harzianum \\ T. koningii 1 \\ Consensus \\ T. koningii 2 \\ T. harzianum \\ T. koningii \\ Consensus \\ T. koningii 2 \\ T. harzianum \\ T. koningii 1 \\ Consensus \\ T. koningii 2 \\ T. harzianum \\ T. koningii 1 \\ Consensus \\ T. koningii 2 \\ T. harzianum \\ T. koningii 1 \\ Consensus}

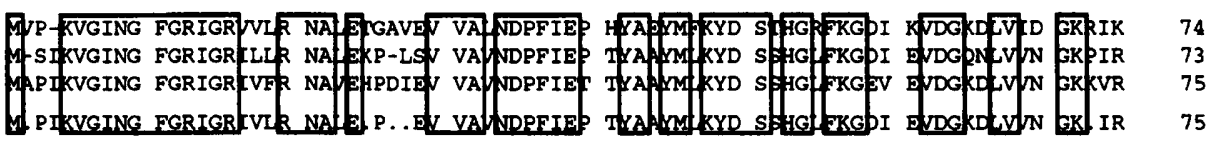

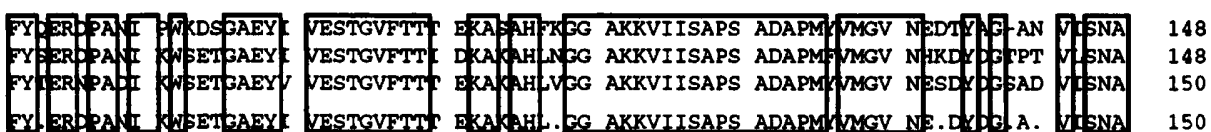

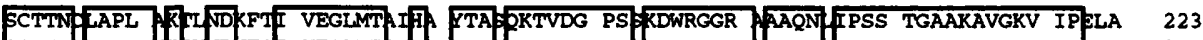

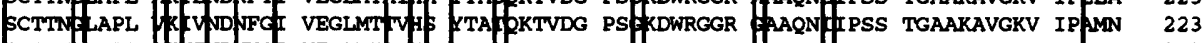

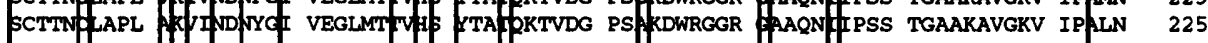

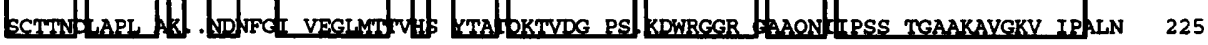
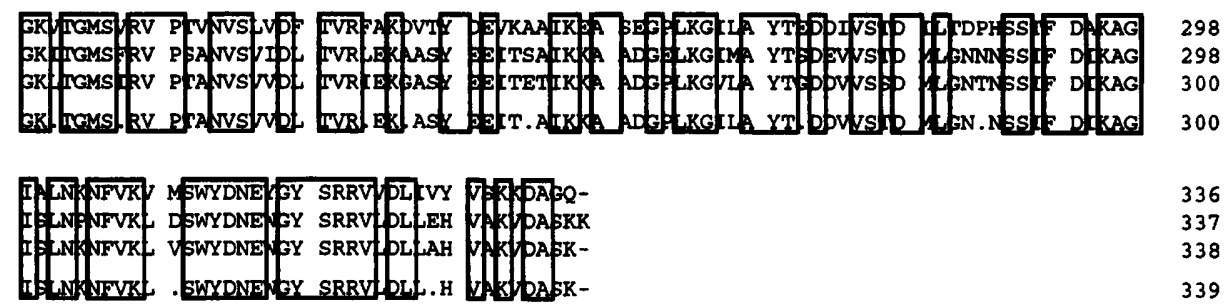

Fig. 3. Homology of $T$. harzianum gpd amino acid sequence with those encoded by both gpd genes from $T$. koningii (Watanabe et al., 1993), aligned using GeneWorks (Intelligenetics). Boxes indicate regions of identity.

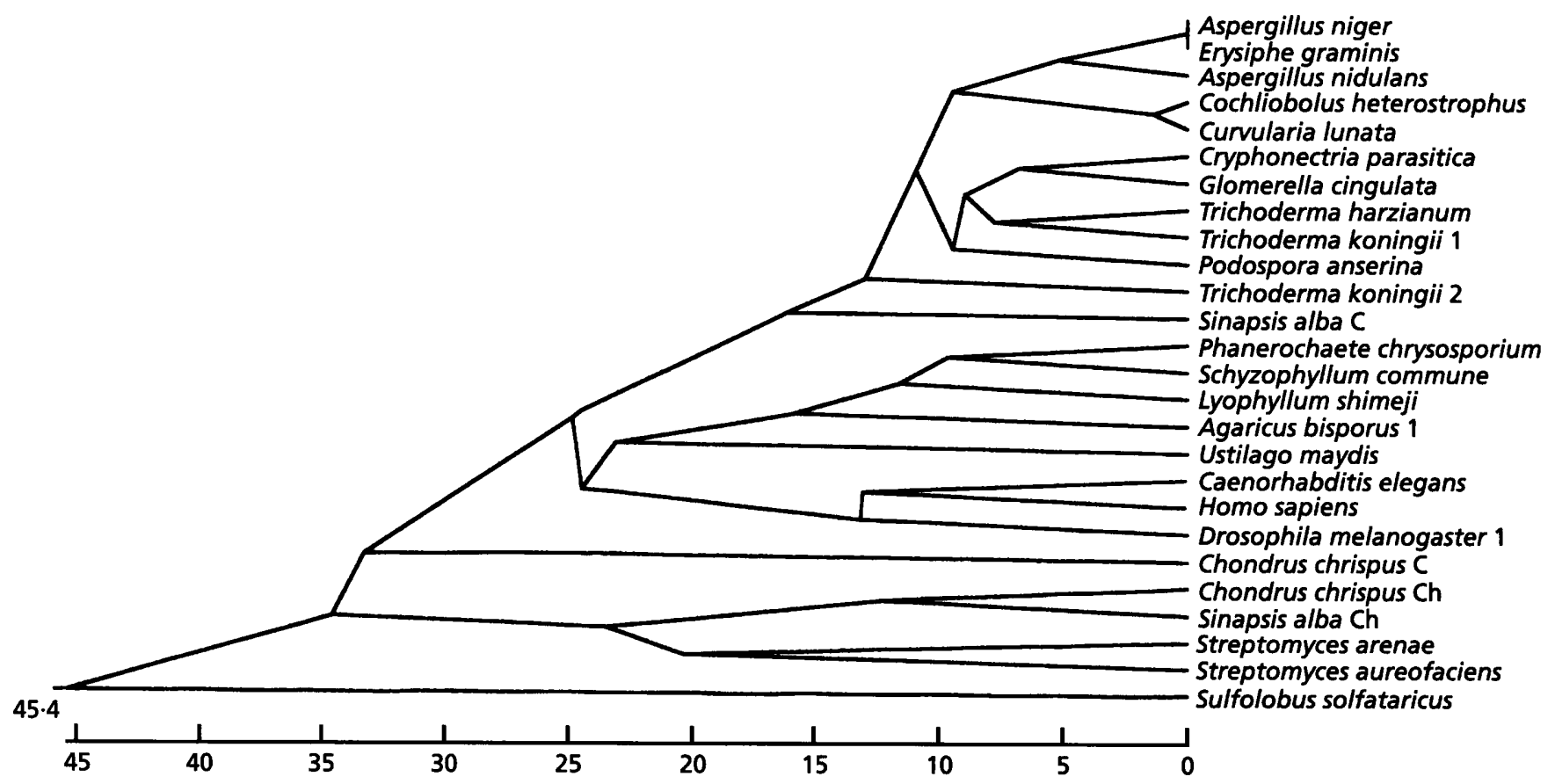

Fig. 4. Dendrogram indicating the relationship of $T$. harzianum to other known GPD protein sequences (EMBL accession nos: M33539; X52674; X63516; X58718; X53996; X62824; X07879; D88426; X99652; X99732; M81724; M81754; M93427; M81727; M11259; D14518; D14519; M11254; SWISS-PROT accession nos: 1730161; 729551; 706953; 462136; 462135; 120659; 120675; P00354). Diagram was generated using the program LASER GENE (DNASTAR); the scale indicates distance.

described below, indicates that the cDNA clone corresponds to the abundant $39 \mathrm{kDa}$ polypeptide against which the antibody was raised. The antibody recognized a single spot in Western blots of two-dimensional gels (data not shown). It is still possible that other downregulated protein(s), less abundant than GAPDH, are present in the original antigen, but no clones other than $g p d$ have been isolated so far. 


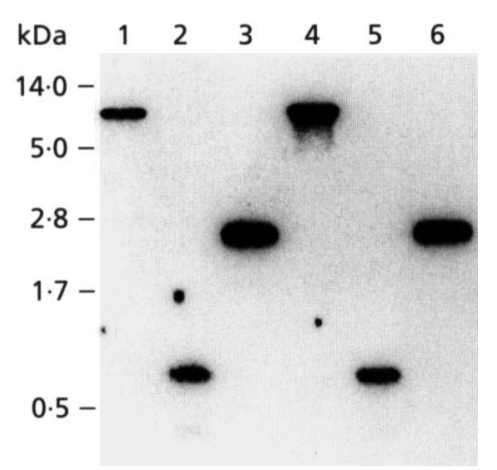

Fig. 5. Southern analysis of gpd. Genomic DNA ( $7 \mu \mathrm{g}$ per lane) of strains ATCC 32173 (lanes 1-3) and IMI 206040 (lanes 4, 5) was digested with BamHI (lanes 1, 4), HindIII (lanes 2, 5) and Sall (lanes 3,6$)$, separated on a $0.8 \%$ agarose gel, blotted to Hybond-N+ and probed with gpd CDNA (Xhol fragment from pGPDA1). Molecular mass markers: גPstl digest.

\section{Characterization of gpd sequences}

The cDNA clone pGPD1A has extensive homology to glyceraldehyde-phosphate dehydrogenase $(g p d)$ sequences from other organisms, as discussed in detail below. It contains the entire coding sequence, as well as the $3^{\prime}$ untranslated region; there is a possible polyadenylation signal at $1328 \mathrm{bp}$, ATAAA, $36 \mathrm{bp}$ upstream from the poly(A). The ATG at $10 \mathrm{bp}$ from the start of the cDNA is likely to encode the initial methionine residue, based on homology to other $g p d$ sequences; the sequence surrounding this codon, GCCATCATGTC, is quite consistent with the consensus for translation start sites in Neurospora crassa (Bruchez, 1993). Most of the $5^{\prime}$ untranslated region appears to be missing from the cDNA clone, based on the size of the mRNA $(1 \cdot 8 \mathrm{~kb})$. The molecular mass calculated from the sequence is $36 \mathrm{kDa}$, somewhat smaller than originally estimated from migration on SDS-PAGE ( $39 \mathrm{kDa}$, Figs 1 and 2).

The deduced amino acid sequence shows strong homology, $78 \%$ identity (Fig. 3 ) to a gpd sequence (GAPDH I) from Trichoderma koningii, another member of the genus. The second gpd gene of $T$. koningii, encoding GAPDH II, shows lower homology $(62 \%)$ to $T$. harzianum, and also appears distant from many other fungal sequences (Fig. 4, and Jungehulsing et al., 1994). GAPDH II is an unusual GPD, which is resistant to the mycotoxin koningic acid produced by $T$. koningii (Watanabe et al., 1993). Among sequences tested (Fig. 4), T. harzianum is, as expected, closest to other ascomycetes, with the exception of T. koningii GAPDH II. T. harzianum fits into the pattern reported by Smith (1989), in which the gpd sequences of filamentous ascomycetes are closer to other filamentous fungi and to animals than to ascomycete yeasts.

Southern analysis of total DNA of both strains used in this study showed an identical pattern (Fig. 5). The hybridizing band in the SalI digests probably represents

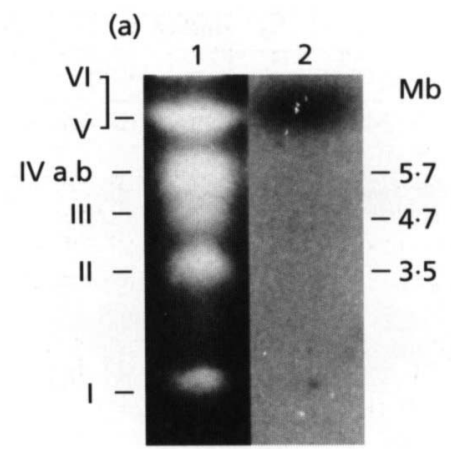

(b)

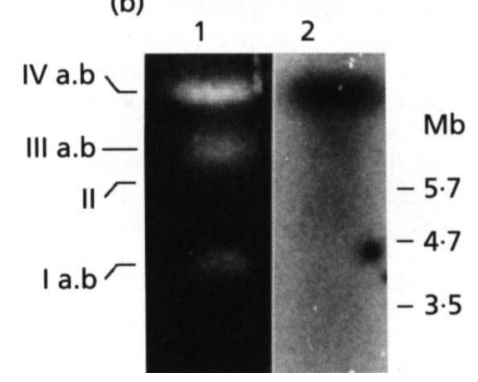

Fig. 6. Chromosome localization of gpd. Chromosomes of strains IMI 206040 (a) and ATCC 32173 (b) were separated by contour-clamped homogeneous field electrophoresis, blotted and probed with gpd cDNA. Lanes: 1, ethidium-bromidestained gel; 2, hybridization of gpd. Chromosomes are numbered according to Herrera-Estrella et al. (1993).

two fragments, consistent with the SalI site at $568 \mathrm{bp}$ in the cDNA sequence; Bam HI does not cut within the cDNA sequence, again consistent with the genomic Southern blot. There is a HindIII site at $931 \mathrm{bp}$ in the cDNA; two additional sites are needed to explain the restriction pattern on the genomic Southern. The small (about $0.4 \mathrm{~kb}$ ) band was detected in two independent experiments. It did not increase in intensity upon hybridization at lower stringency so it seems unlikely that this band indicates another gpd copy, though this cannot be completely excluded. The additional HindIII sites might be located just outside the available cDNA sequence, or in introns; the gpd gene of $A$. nidulans contains seven introns, five in or before the translational start site, and two near the $3^{\prime}$ end (Punt et al., 1988).

To localize the gpd gene on the molecular karyotype, chromosomes of both strains were separated by contourclamped homogeneous electric field electrophoresis, and probed with the gpd cDNA. The hybridization signal corresponds to the location of chromosomes $\mathrm{V}$ or VI (IMI 206040) and their homologues IVa or IVb in ATCC 32173 (Fig. 6). The pgk gene was also localized to chromosome V or VI of T. harzianum IMI 206040 (Herrera-Estrella et al., 1993); whether this means that glycolysis genes in Trichoderma are clustered remains to be investigated.

Developmental regulation of the mRNA hybridizing to 


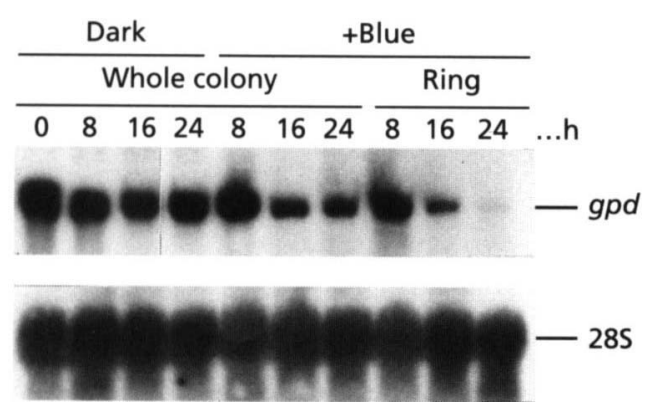

Fig. 7. Regulation of gpd mRNA levels during photoinduced conidiation. Colonies were grown in total darkness and photoinduced as for Figs 1 and 2. Upper panel, Northern blot of total RNA (15 $\mu \mathrm{g}$ per lane), probed with the Xhol fragment from PGPDA1. Lower panel, hybridization of a replica blot with a fragment of the human 28S rRNA gene (see Methods) as a control for equal loading of the lanes. Experiments were carried out twice for all time-points, except for 0 and $24 \mathrm{~h}$ which were done four times.

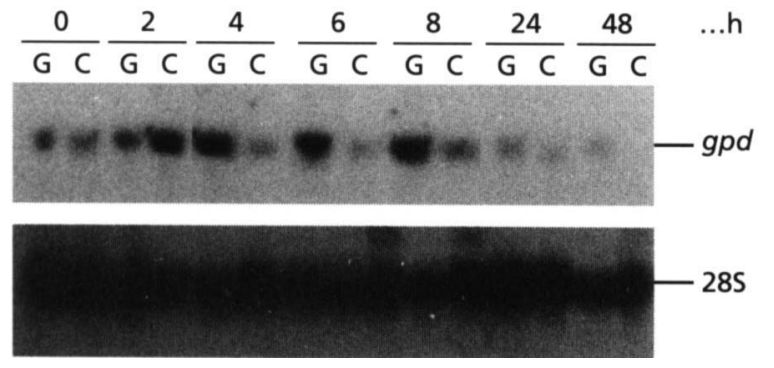

Fig. 8. Regulation of gpd mRNA levels during simulated mycoparasitism. Samples were harvested at the indicated times of growth on minimal medium with glucose (G) or on Rhizoctonia cell walls (C). Upper panel, Northern blot of total RNA ( $20 \mu \mathrm{g}$ per lane), probed with the gpd CDNA as in Fig. 7. Lower panel, second hybridization of the same blot with a fragment of the human 285 rRNA gene, as a control for equal loading of the lanes. The experiment was repeated three times.

the pGPD1A cDNA is shown in Fig. 7. The transcript, of about $1.8 \mathrm{~kb}$, is very abundant in dark-grown mycelia, and is strongly repressed in developing conidiophores. In contrast to the polypeptide abundance (Fig. 2), the decrease in mRNA level was also found for RNA samples from the entire colony, but the regulation is much more striking in the conidiophore samples. After $48 \mathrm{~h}$ growth on minimal medium with $2 \%$ glucose, the gpd transcript is abundant (time zero of the simulated mycoparasitism experiment, Fig. 8). From transfer to $2 \mathrm{~h}$, the transcript level increased on both glucose and cell walls. At 4-8 h, the gpd mRNA was markedly repressed in cultures growing on cell walls as compared to the glucose controls. By 24 and $48 \mathrm{~h}$ after transfer, the transcript level decreased in cultures growing on either glucose or cell walls, and at $48 \mathrm{~h}$ remained somewhat higher in the cell-wall-grown cultures than on glucose (Fig. 8). Glucose is totally exhausted after about $14 \mathrm{~h}$ of

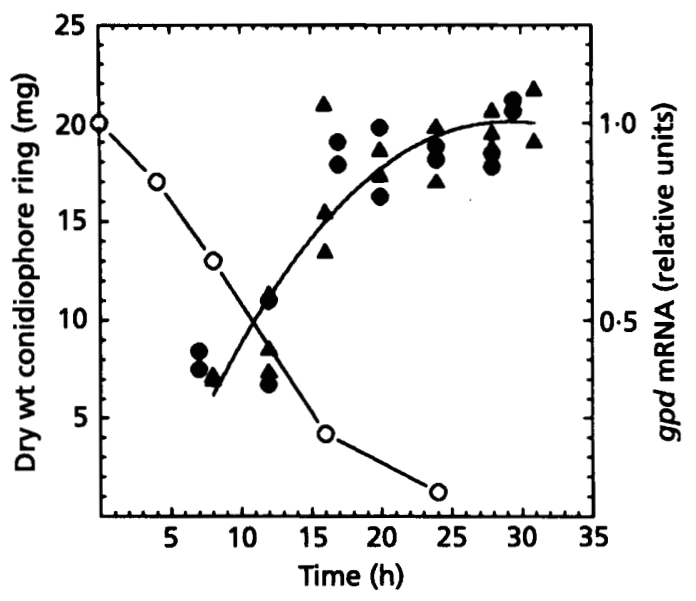

Fig. 9. Growth kinetics of the conidiophore ring, compared with gpd down-regulation. (O, $\Delta$ ) Rings of developing conidiophores were harvested at the indicated times after photoinduction with a saturating pulse of blue light, as in Fig. 1. Each symbol indicates the mean of three colonies; different symbols indicate independent experiments. (O) Steady-state gpd mRNA levels were measured by densitometry of Northern blots, as in the upper panel of Fig. 7; each symbol indicates the mean of two independent experiments. Equal loading was confirmed by ethidium bromide staining of the gels.

growth under these conditions, perhaps explaining the decrease in both transcripts. In the time window at 4-8 h when the mRNA is down-regulated, the cultures are still growing.

\section{Temporal comparison of gpd down-regulation and conidiophore development}

Both simulated mycoparasitism and conidiation represent a shift to less favourable conditions, and in both cases, growth eventually slows down or stops. The synchronous development of conidiophores provided an opportunity to determine which occurs first, downregulation of $g p d$ expression, or the decrease in growth rate. The growth curve for the conidiophore ring induced by blue light is shown in Fig. 9. The decrease in mRNA level occurs together with morphogenesis, and is very clear by $16 \mathrm{~h}$ after photoinduction, at a time when the growth rate of the conidiophore ring is maximal (Fig. 9).

\section{DISCUSSION}

Although $g p d$ is considered to be a constitutively expressed gene in filamentous fungi, there is precedent for regulation of $g p d$ genes in other organisms, for example in vertebrates (Dobson et al., 1987), Drosophila (Sun et al., 1988) and Caenorhabditis elegans (Huang et al., 1989). The nuclear genes encoding chloroplast GPD in Arabidopsis thaliana are light-regulated, albeit upward rather than downward (Kwon et al., 1994). Furthermore, phosphoglycerate kinase (PGK) mRNA is 
also down-regulated in T. harzianum during conidiation and simulated mycoparasitism (Goldman et al., 1992). It has been reported that constitutively expressed proteins, such as GPD or the plasma membrane ATPase, are regulated by glucose in yeast (Capieaux et al., 1989; Rao et al., 1993). In yeast cells entering the stationary phase, however, GPD was one of the few enzymes that continued to be expressed at high levels (Boucherie, 1985). Adams \& Timberlake (1990) showed that constitutive expression of $\mathrm{brlA}$ in Aspergillus growing in favourable conditions induces sporulation, and at the same time represses two genes which are normally highly expressed, alcA and aldA. They proposed that the induction of sporulation leads to a generalized metabolic shutdown. Trichoderma, when exposed to blue light, behaves in a similar way: the colony sporulates, even though the nutrient conditions are favourable. The view that blue light causes a transient metabolic stress (Gressel \& Rau, 1983) fits well with this picture. Either blue light or nitrogen stress can regulate many of the same genes in Neurospora (Sokolovsky et al., 1992), though this does not yet imply that stress acts downstream from light in the transduction chain. In mycoparasitism, like conidiation, the organism must contend with less favourable conditions. One could argue that the repression of gpd may simply result from a slowdown in growth. That this is not the case is clear from Fig. 9; down-regulation begins early and continues while the conidiophores are growing most rapidly. By $24 \mathrm{~h}$ after induction, growth is slow, conidia are maturing, and the $g p d$ mRNA level is very low (Figs 7 and 9). Developing conidiophores have rapid growth and metabolism, as shown by rapid incorporation of radioactive metabolites such as methionine $(B$. A. Horwitz, unpublished). Though we do not have unequivocal proof that the protein recognized by the antibody (Fig. 2) consists entirely of GPD, there is much circumstantial evidence (cross-reactivity with the fusion protein from the $g p d$ clone; single spot on $2 \mathrm{~d}$ gels; the fact that GPD is an abundant protein; down-regulation of mRNA and of the polypeptide recognized by the antibody). If so, the amount of enzyme remaining in conidiophores (Fig. 2) would need to be enough to support spore maturation, and germ tube emergence upon germination. There is no evidence from Southern hybridizations and library screening for more than one gpd copy in Trichoderma.

The down-regulation of $g p d$ may have consequences for the use of $g p d$ expression signals to drive dominant selectable marker genes such as hygromycin phosphotransferase (Punt et al., 1987). It is often observed that hygromycin inhibits sporulation of otherwise resistant transformants. Sporulation is inhibited under some conditions that permit growth, for example nutrient limitation in auxotrophs (Horwitz \& Gressel, 1983; Serlupi-Crescenzi et al., 1983). However, preliminary experiments indicated that the $A$. nidulans $g p d$ promoter confers high levels of $h p b$ mRNA in developing conidiophores, while at the same time the Trichoderma $g p d$ mRNA levels sharply decreased (data not shown). Thus, the down-regulation should not create any difficulty in using the $g p d$ promoter to express heterologous genes in conidiophores and conidia, although further work is needed to pursue this question.

\section{ACKNOWLEDGEMENTS}

We are grateful to Ana Gutierrez for RNA from simulated mycoparasitism cultures, to Isela Gómez for the CHEF gels, and to Rivka Amit for help in the preparation of the antibody. We thank Dr Peter J. Punt for providing us with pAN7-1 and Dr Everardo López for critical reading of the manuscript. This work was supported in part by grants from CONACYT N9108-0440 to A.H.-E. and from the Israel Academy of Sciences $524 / 91$ to B.A.H.

\section{REFERENCES}

Adams, T. H. \& Timberlake, W. E. (1990). Developmental repression of growth and gene expression in Aspergillus. Proc Natl Acad Sci USA 87, 5405-5409.

Adams, T. H., Boylan, M. T. \& Timberlake, W. E. (1988). Brla is necessary and sufficient to direct conidiophore development in Aspergillus nidulans. Cell 54, 353-362.

Arpaia, G., Loros, J. J., Dunlap, J. C., Morelli, G. \& Macino, G. (1993). The interplay of light and the circadian clock. Independent dual regulation of clock-controlled gene ccg2 (eas). Plant Physiol 102, 1299-1305.

Ausubel, F. B., Kingston, R., Moore, R. E., Seidman, D. D., Smith, J. G. \& Struhl, K. (1987). Current Protocols in Molecular Biology. New York: Wiley.

Ballario, P., Vittorioso, P., Magrelli, A., Talora, C., Cabibbo, A. \& Macino, G. (1996). White collar-1, a central regulator of blue light responses in Neurospora, is a zinc finger protein. EMBO J 15, 1650-1657.

Baum, D. \& Horwitz, B. A. (1991). Changes in synthesis and abundance of specific polypeptides at early and late stages of bluelight-induced sporulation of Trichoderma. J Photochem Photobiol B Biol 11, 117-128.

Betina, V. (1984). Photoinduced conidiation in Trichoderma viride. Int J Microbiol 2, 55-68.

Boucherie, H. (1985). Protein synthesis during transition and stationary phases under glucose limitation in Saccharomyces cerevisiae. J Bacteriol 161, 385-392.

Bruchez, J. J. P., Eberle, J. \& Russo, V. E. A. (1993). Regulatory sequences involved in the translation of Neurospora crassa mRNA: Kozak sequences and stop codons. Fungal Genet Newsl 40, 85-88.

Capieaux, E., Vignais, M.-L., Sentenac, A. \& Goffeau, A. (1989). The yeast $\mathrm{H}^{+}$-ATPase gene is controlled by the promoter-binding factor TUF. J Biol Chem 264, 7437-7446.

Carsolio, C., Gutierrez, A., Jimenez, B., Van Montagu, M. \& Herrera-Estrella, A. (1994). Characterization of ech-42, a Trichoderma harzianum endochitinase gene expressed during mycoparasitism. Proc Natl Acad Sci USA 91, 10903-10907.

Chet, I. \& Baker, R. (1981). Isolation and biocontrol potential of Trichoderma hamatum from soil naturally suppressive of $R$ hizoctonia solani. Phytopathology 71, 286-290.

Dobson, D. E., Groves, D. L. \& Spiegelman, B. M. (1987). Nucleotide sequence and hormonal regulation of mouse glycerolphosphate dehydrogenase messenger RNA during adipocyte and muscle cell differentiation. J Biol Chem 262, 1804-1809.

Farkas, V., Greisk, M., Kolarova, N., Sulova, Z. \& Sestak, S. (1990). Biochemical and physiological changes during photoinduced 
conidiation and derepression of cellulase synthesis in Trichoderma. In Trichoderma reesei Cellulases: Biochemistry, Genetics, Physiology and Applications, pp. 139-151. Edited by C. P. Kubicek, D. E. Eveleigh, H. Esterbauer, W. Steiner \& W. M. Kubicek-Pranz. London: Royal Chemical Society.

Flores, A., Chet, I. \& Herrera-Estrella, A. (1997). Improved biocontrol activity of Trichoderma harzianum by overexpression of the proteinase encoding gene prb1. Curr Genet 31, 30-37.

Geremia, R. A., Goldman, G. H., Jacobs, D., Ardiles, W., Vila, S. B., Van Montagu, M. \& Herrera-Estrella, A. (1993). Molecular characterization of the proteinase-encoding gene $p r b 1$ related to mycoparasitism by Trichoderma harzianum. Mol Microbiol 8, 603-613.

Goldman, G. H., Geremia, R. A., Caplan, A. B., Vila, S. B., Villarroel, R., Van Montagu, M. \& Herrera-Estrella, A. (1992). Molecular characterization and regulation of the phosphoglycerate kinase gene from Trichoderma viride. Mol Microbiol 6, 1231-1242.

Gressel, J. \& Rau, W. (1983). Photocontrol of fungal development. In Photomorphogenesis - Encyclopedia of Plant Physiology, vol. 16B, pp. 603-609. Edited by W. Shopshire \& H. Mohr. Berlin: Springer.

Harlow, E. \& Lane, D. (1988). Antibodies: a Laboratory Manual. Cold Spring Harbor, NY: Cold Spring Harbor Laboratory.

Herrera-Estrella, A., Goldman, G. H., Van Montagu, M. \& Geremia, R. A. (1993). Electrophoretic karyotype and gene assignment to resolved chromosomes of Trichoderma spp. Mol Microbiol 7, 515-521.

Horwitz, B. A. \& Gressel, J. (1983). Elevated riboflavin requirement for postphotoinductive events in sporulation of a Trichoderma auxotroph. Plant Physiol 71, 200-204.

Horwitz, B. A., Perlman, A. \& Gressel, J. (1990). Induction of Trichoderma sporulation by nanosecond laser pulses: evidence against cryptochrome cycling. Photochem Photobiol 51, 99-104.

Huang, X. Y., Barrios, L. A. M., Vonkhorporn, P., Honda, S., Albertson, D. G. \& Hecht, R. M. (1989). Genomic organization of the glyceraldehyde-3-phosphate dehydrogenase gene family of Caenorhabditis elegans. J Mol Biol 206, 411-424.

Inbar, J. \& Chet, I. (1995). The role of recognition in the induction of specific chitinases during mycoparasitism by Trichoderma harzianum. Microbiology 141, 2823-2829.

Jungehulsing, U., Arntz, C., Smit, R. \& Tudzynski, P. (1994). The Claviceps purpurea glyceraldehyde-3-phosphate dehydrogenase gene: cloning, characterization, and use for the improvement of a dominant selection system. Curr Genet 25, 101-106.

Kwon, H.-B., Park, S.-C., Peng, H.-P., Goodman, H. M., Dewdney, J. \& Shih, M. C. (1994). Identification of a light-responsive region of the nuclear gene encoding the B subunit of chloroplast glyceraldehyde 3-phosphate dehydrogenase from Arabidopsis thaliana. Plant Physiol 105, 357-367.

Lauter, F. R., Russo, V. E. A. \& Yanofsky, C. (1992). Developmental and light regulation of eas, the structural gene for the rodlet protein of Neurospora. Genes Dev 6, 2373-2381.
Lora, J. M., de la Cruz, J., Benitez, T., Llobell, A. \& Pintor-Toro, J. A. (1994). A putative catabolite-repressed cell wall protein from the mycoparasitic fungus Trichoderma harzianum. Mol Gen Genet 242, 461-466.

Punt, P. J., Oliver, R. P., Dingemanse, M. A., Pouwels, P. H. \& van den Hondel, C. A. M. J. J. (1987). Transformation of Aspergillus based on the hygromycin b resistance marker from Escherichia coli. Gene 56, 117-124.

Punt, P. J., Dingemanse, M. A., Jacobs-Meijsing, B. H. M., Pouwels, P. H. \& van den Hondel, C. A. M. J. J. (1988). Isolation and characterization of the glyceraldehyde-3-phosphate dehydrogenase gene of Aspergillus nidulans. Gene 69, 49-57.

Rao, R. D., Drummond-Barbosa, D. \& Slayman, C. W. (1993). Transcriptional regulation by glucose of the yeast PMA1 gene encoding the plasma membrane $\mathrm{H}^{+}$-ATPase. Yeast 9, 1075-1084.

Roberts, A. N. \& Yanofsky, C. (1989). Genes expressed during conidiation in Neurospora crassa: characterization of con-8. Nucleic Acids Res 17, 197-214.

Serlupi-Crescenzi, O., Kurtz, M. B. \& Champe, S.P. (1983). Developmental defects resulting from arginine auxotrophy in Aspergillus nidulans. J Gen Microbiol 129, 3535-3544.

Smith, T. L. (1989). Disparate evolution of yeasts and filamentous fungi indicated by phylogenetic analysis of glyceraldehyde-3phosphate dehydrogenase genes. Proc Natl Acad Sci USA 86, 7063-7066.

Sokolovsky, V. Y., Lauter, F. R., Muller-Rober, B., Ricci, M., Schmidhauser, T. J. \& Russo, V. E. A. (1992). Nitrogen regulation of blue light-inducible genes in Neurospora crassa. J Gen Microbiol 138, 2045-2049.

Stringer, M. A., Dean, R. A., Sewall, T. C. \& Timberlake, W. E. (1991). Rodletless, a new Aspergillus developmental mutant induced by directed gene inactivation. Genes Dev 5, 1161-1171.

Sun, X. H., Tso, J. Y., Lis, J. \& Wu, R. (1988). Differential regulation of the two glyceraldehyde-3-phosphate dehydrogenase genes during Drosophila development. Mol Cell Biol 8, 5200-5205.

Timberlake, W. E. (1993). Translational triggering and feedback fixation in the control of fungal development. Plant Cell 5, 1453-1460.

Urey, J. C. (1971). Enzyme patterns and protein synthesis during synchronous conidiation in Neurospora crassa. Dev Biol 26, 17-27.

Watanabe, H., Hasumi, K., Fukushima, Y., Sakai, K. \& Endo, A. (1993). Cloning of two isozymes of Trichoderma koningii glyceraldehyde-3-phosphate dehydrogenase with different sensitivity to koningic acid. Biochim Biophys Acta 1172, 43-48.

Weiss, B. \& Turian, G. (1966). Enzyme activity and cell differentiation in Neurospora. Am J Bot 46, 555-559.

Received 17 February 1997; revised 28 May 1997; accepted 20 June 1997. 